\title{
Ibiza acoge las XIX Jornadas de Arqueología Fenicio-Púnica
}

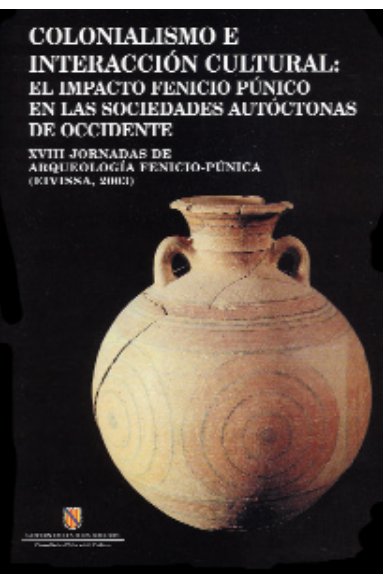

Las Jornadas de Arqueología Fenicio-Púnica tienen una periodicidad anual, y consisten en un ciclo de cinco conferencias impartidas por reconocidos investigadores, catedráticos y profesores universitarios o conservadores de museos, que el Museo Arqueológico de Ibiza y Formentera, dependiente de la Dirección de Cultura del Gobierno Balear, viene organizando desde 1986.

La primera convocatoria tuvo como objetivo dar a conocer las novedades de la investigación feniciopúnica que se venía desarrollando en nuestro país en aquellos momentos. Sin embargo, su buena acogida impulsó, en años sucesivos, la convocatoria de nuevas ediciones de amplia y diversa temática siempre dentro del ámbito del mundo fenicio-púnico, hasta el punto de convertirse en una de las actividades culturales más importantes que tienen lugar en otoño en la isla de Ibiza.

La última convocatoria se celebró entre los días 29 de noviembre y 3 de diciembre de 2004, bajo el título Guerra y ejército en el mundo feniciopúnico. Las cinco conferencias que compusieron estas XIX Jornadas de Arqueología Fenicio-Púnica fueron:

> "Poliorcética y Guerra Naval en el mundo Fenicio" impartida por Jaime Alvar Ezquerra

> "La armada cartaginesa: El remo y espolón en el Mediterráneo Occidental" pronunciada por Rafael Rebolo Gómez

> "El Ejército Cartaginés anterior a la Segunda Guerra Púnica", expuesta por Jaime Gómez de Caso Zuriaga

> "El Ejército de Anibal: similitudes y diferencias con otros ejércitos cartagineses y romanos de la Segunda Guerra Púnica", presentada por Fernando Quesada Sanz

> "Los Mercenarios Baleáricos", ofrecida por Adolfo J. Domínguez Monedero
El encuentro tiene como principal objetivo presentar en primera instancia, a investigadores, estudiosos y al público interesado, las novedades que en el ámbito nacional se van produciendo en el vasto campo de los estudios fenicio-púnicos, a la vez que un lugar de encuentro y debate, donde se expongan las diferentes tendencias y puntos de vista sobre las cuestiones planteadas los trabajos de investigación y novedades de los investigadores españoles, sobre todo en el ámbito hispano.

\section{JORNADES D'ARQUEOLOGIA FINICIOPÚNICA cocade / Crtacit EN $5 L$ MdN FFMCVumín:}

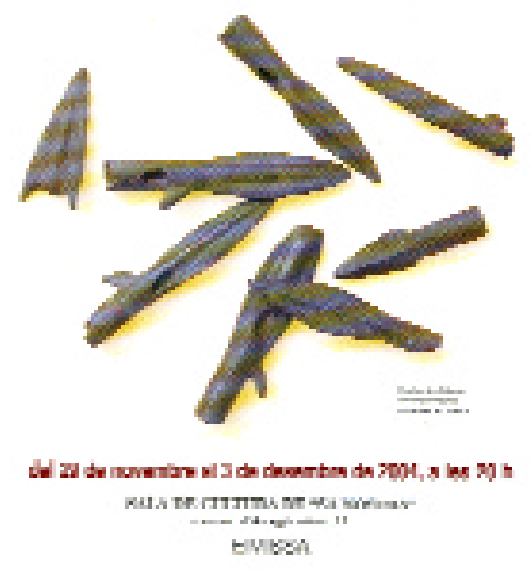

Igualmente su finalidad última es la publicación de las ponencias en un volumen, que se edita antes de la realización de la siguiente convocatoria, a los efectos de poner al alcance de investigadores y estudiosos el resultado final de las sesiones, para que pueda ser utilizado en el ámbito universitario o entre los estudiosos interesados en el tema publicado.

Jordi H. Fernández

Museo Arqueológico de Ibiza y Formentera

Andalucía estrena portal de museos

El pasado 23 de febrero se inauguró el nuevo portal de Museos de Andalucía, cuyo avance se presentó por parte de la Dirección General de Museos de la Consejería de Cultura hace ahora unos meses.

El portal cuenta con información de las actividades que desarrolla la Dirección General de Museos, además de facilitar un sencillo acceso, a través de un mapa dinámico de Andalucía, a cualquiera de las páginas web de las 21 instituciones incluidas: 16 museos, 4 conjuntos arqueológicos y 1 conjunto monumental.

Acceso: www.juntadeandalucia.es/cultura/museos 